\title{
BCL3 wt Allele
}

National Cancer Institute

\section{Source}

National Cancer Institute. BCL3 wt Allele. NCI Thesaurus. Code C52517.

Human BCL3 wild-type allele is located within 19q13.1-q13.2 and is approximately $11 \mathrm{~kb}$ in length. This allele, which encodes B-cell lymphoma 3-encoded protein, plays a role in the modulation of transcription. In some cases of B-cell leukemia, the gene is involved a translocation $\mathrm{t}(14 ; 19)(\mathrm{q} 32 ; \mathrm{q} 13.1)$, which embeds this gene in the immunoglobulin-alpha gene locus. 